Brazilian Journal

of Chemical

ISSN 0104-6632

Engineering

\title{
ADAPTATION BEHAVIOUR OF BACTERIAL SPECIES AND IMPACT ON THE BIODEGRADATION OF BIODIESEL-DIESEL
}

\author{
E. Fosso-Kankeu*, S. Marx and A. Brink \\ School of Chemical and Minerals Engineering, North-West University, \\ Private Bag, X6001, Potchefstroom, 2520, South Africa. \\ Phone: +27 182991659 \\ E-mail:kaelpfr@yahoo.fr
}

(Submitted: August 4, 2015; Revised: January 28, 2016; Accepted: January 29, 2016)

\begin{abstract}
Two bacteria, namely Bacillus subtilis and Pseudomonas aeruginosa were exposed to different concentrations of diesel to increase their adaptation to the fossil fuel, and were used for the degradation of diesel-biodiesel blends. The biodegradation rate was evaluated using the redox indicator 2,6-dichlorophenol indophenol (DCPIP) test and gravimetric analysis. The preliminary exposure of cells to diesel proved to improve their biodegradation capacities, and exposure to a higher concentration (70\%) of diesel resulted in maximum biodegradation of up to $58.38 \mathrm{~g}$ and $1.78 \mathrm{~g}$ of degraded oil per CFU/mL $\left(10^{10}\right)$ for P. aeruginosa and B. subtilis respectively. It was found that the adapted cells preferably used diesel in the blend. $P$. aeruginosa and $B$. subtilis exhibited different adaptation capabilities and biodegradation behaviour. Biodiesel stimulated the biodegradation of the diesel-biodiesel blends by non-adapted cells only; the adapted cells exhibited a different behaviour.

Keywords: Diesel-biodiesel blend; induced adaptation; biodegradation; P. aeruginosa; B. subtilis.
\end{abstract}

\section{INTRODUCTION}

The dispersion of oil spills from point sources (tankers, pipelines and oil wells) and from nonpoint sources (routine discharges of fuel from commercial vessels or leakage from recreational boats) are contributing factors to the destabilisation of the ecosystem reported now and then around the world (Ribeiro et al., 2013; Meyer et al., 2014). Diesel oil contains thousands of hydrocarbons, which are highly toxic to many organisms, including humans (Yoon-Suk et al., 2009). Remediation of fuel contaminated water could be achieved by physical methods, making use of techniques such as floating booms, skimmers and oil-water separators (Fei et al., 2015). Chemical methods consist mainly of the dissolution of oil in water using chemical dispersants such as surfactants (Kaczorek et al., 2010). The above methods have been superseded by biological methods, which rely mostly on metabolic activities of microorganisms for the removal of pollutants and detoxification of water and are considered to be green processes. Microorganisms can degrade crude oil and have been exploited in the bioremediation of contaminated soils at large scale (Biogenie, 1995; Zittwitz et al., 2000). Surfactant-producing bacteria are very effective in the degradation of oil and are often isolated from contaminated sites. Chandankere et al. (2013) isolated an efficient bio-surfactant-producing bacterium, Bacillus methylotrophicus from a petroleum reservoir in northeast China. Nine bacterial strains isolated from a polluted stream in Nigeria by Adebusoye et al. (2007) could degrade crude oil. The ability of a surfactant to increase the dispersion of hydrocarbons, as well as the contact area with microorganisms is crucial for the biodegradation process (Banat et al., 2000; Kaczorek et al., 2010). Crude

*To whom correspondence should be addressed 
oil biodegradability potential of Pseudomonas aeruginosa ZJU was enhanced by stimulation of rhamnolipid production after preservation in a crude oil containing medium (Tang et al., 2007).

Hydrocarbon oil spills in terrestrial regions widely affect the microbial population in the topsoil (Bundy et al., 2002) and deeper soil regions (Krumholz, 1998). The nutrient cycle of subsurface soil environments is mainly disrupted by the decrease in microbial activity, affecting the recycling of macro nutrients, affecting the oxygen availability to microorganisms (Krumholz, 1998). Maila et al. (2005) reported that microbial density and diversity decrease in deeper soil regions as a response to diesel contamination. The ability of utilizing and/ or surviving toxic contaminants often determines the composition of microbial communities (Yoon-Suk et al., 2009). It has been reported (Michaud et al., 2004) that short-chain alkanes $(<\mathrm{C} 10)$ may become more soluble in water as they last longer, therefore increasing their toxicity towards microorganisms and delaying the efficiency of biodegradation (Atlas, 1981; Leahy and Cowell, 1990). The ability of microorganisms to adapt in contaminated areas through biotransformation may therefore be very important for the biodegradation of oil in both terrestrial and aquatic systems (Kleinsteuber et al., 2006; Zhen-Yu et al., 2008). Indigenous microorganisms adapted to the environment have been reported to have considerable oil bioremediation potential and therefore contribute significantly in the cleanup process (Margesin and Schinner, 2001; Norman et al., 2004; Vacca et al., 2005).

The main environmental concern considering fossil diesel is the low biodegradation rate in comparison with an alternative biodiesel source. Although simple aromatic compounds could be readily removed via microbial degradation, more complex compounds, including total petroleum hydrocarbons, appear to be more persistent in crude-oil-contaminated areas (Yoon-Suk et al., 2009).

In 2012, the South African Department of Energy announced that there will be a minimum blending ratio of $5 \%$ biodiesel, in an attempt to reduce the dependence on imported crude oil. For most of the investigations carried out at the bench scale, it was found that microorganisms easily biodegrade biodiesel and blends higher than B10 compared to fossil diesel; assessing in the laboratory the ability of fungi to biodegrade soy-derived blended diesel, Bucker et al. (2011) found that the blend containing a higher proportion of vegetable oil biodiesel was much susceptible to biodegradation. A similar trend was observed by Meyer et al. (2014), who found that the presence of biodiesel increases the biodegradation of petroleum diesel. Although biodiesel is reported to be readily biodegradable compared to fossil diesel, there are conflicting opinions about the significance of blending on the biodegradation of diesel (Zhang et al., 1998; Sorensen et al., 2011). According to Pasqualino et al. (2006), there is a synergic effect in the biodegradation of blended biodiesel, while for others (Owsianiak et al., 2009) an increase in biodegradation will not necessarily be achieved through blending of biodiesel in fossil diesel.

The current study aims to investigate the concurrent impact of microbial adaptation and biodiesel blend grades on the biodegradation of blended biodiesel.

\section{METHODOLOGY}

\section{Microorganisms}

Pseudomonas aeruginosa ATCC 10145 used in this study was kindly offered by the Department of Microbiology, Faculty of Sciences of the North-West University (Potchefstroom-South Africa). This strain has been previously reported (Chayabutra and Yu, 2001) to produce biosurfactants such as rhamnolipids, which are essential in the degradation of fossil oil. Bacillus subtilis sp used in this study has been previously isolated from the mining area (isolate 753_63-F-SEQ (Dlamini et al., 2010)) and has shown good biodegradation capability (Mittal et al., 2013).

\section{Induction of resistance}

Stock cultures of $P$. aeruginosa and B. subtilis species from nutrient agar (composition in g. $\mathrm{L}^{-1}$; meat extract: 1.0; peptone: 5.0 ; yeast extract: 2.0 ; sodium chloride: 8.0; Agar: 15.0) were inoculated in $50 \mathrm{~mL}$ nutrient broth (composition in g.L $\mathrm{L}^{-1}$; meat extract: 1.0; peptone: 5.0; yeast extract: 2.0 ; sodium chloride: 8.0 ), then incubated overnight at $30 \pm 0.5^{\circ} \mathrm{C}$ in a shaking incubator $(160 \mathrm{rpm})$. The culture was transferred into $50 \mathrm{~mL}$ centrifuge tubes and centrifuged at $4000 \mathrm{rpm}$ for $5 \mathrm{~min}$ to harvest the cells from the nutrient broth. The cells in the centrifuge tubes were washed several times with sterile distilled water to remove the residual broth and then the cells were suspended in 30 $\mathrm{mL}$ of Bushnell Haas (BH) medium (composition in g.. $\mathrm{L}^{-1}$ : $0.2 \mathrm{MgSO}_{4}, 0.02 \mathrm{CaCl}_{2}, 1.0 \mathrm{KH}_{2} \mathrm{PO}_{4}, 1.0 \mathrm{~K}_{2} \mathrm{HPO}_{4}, 1.0$ $\mathrm{NH}_{4} \mathrm{NO}_{3}, 0.05 \mathrm{FeCl}_{3}$ ). An equivalent volume of diesel was added to make up a final concentration of $70 \%$ and $1 \%$ $(\mathrm{v} / \mathrm{v})$ diesel in the BH medium. The cells were exposed to $1 \%(\mathrm{v} / \mathrm{v})$ or $70 \%(\mathrm{v} / \mathrm{v})$ diesel for two weeks and eight weeks. The mixtures were incubated at room temperature $\left(25 \pm 1^{\circ} \mathrm{C}\right)$ and gently mixed daily. The cells were transferred to fresh $\mathrm{BH}$ medium every two weeks.

\section{Quantification of cells and viability}

The quantification of the bacterial cells at the beginning of the experiment, as well as the determination of cell viability following exposure to fossil diesel, was done through plate count. To count the cells, an aliquot of $1 \mathrm{~mL}$ 
of inoculum was serially diluted in sterile distilled water and $100 \mu \mathrm{L}$ inoculated in freshly prepared nutrient agar plates (composition in g.L $\mathrm{L}^{-1}$ : meat extract powder 1.0; yeast extract 2.0; peptone 5.0; sodium chloride 5.0; agar 15.0; $\mathrm{pH} 7.4 \pm 0.2$ at $25^{\circ} \mathrm{C}$; Merck Chemicals, SA), and then incubated at $30 \pm 0.5^{\circ} \mathrm{C}$ for $24 \mathrm{~h}$. The number of colonies was expressed as colonies formed per unit (CFU).

\section{Fuel acquisition and preparation}

Fossil diesel (B0) meeting the requirement of the South African Petroleum Industry Association (SAPIA) was purchased from an authorized local fuel vendor in the North West Province of South Africa.

Biodiesel was prepared from refined sunflower oil with a methanol to oil molar ratio of $6: 1$ and $\mathrm{KOH}$ catalyst loading of $1 \mathrm{wt} \%$. The reaction was done in a batch reactor for 90 minutes at a temperature of $60 \pm 1^{\circ} \mathrm{C}$. The biodiesel mostly contained esters of $\mathrm{C} 18: 1$ (42.9 wt\%) and C18:2 (50.9 wt \%).

The following blending ratios $(\% \mathrm{v} / \mathrm{v})$ were prepared for the required investigations; B0; B10; B50; B100.

\section{Gravimetric analysis and extraction}

To monitor the biodegradation rates of diesel blends by induced species; the species were added to $50 \mathrm{~mL}$ of Bushnell Haas $(\mathrm{BH})$ medium in a $250 \mathrm{~mL}$ Erlenmeyer flask containing $1 \mathrm{~g}$ of blended diesel (B0, B10, B50, and $\mathrm{B} 100)$ and incubated in an incubator with shaker (105 rpm) at $30 \pm 0.5^{\circ} \mathrm{C}$ for 7 days. Bushnell-Haas medium is recommended when examining the microbial deterioration of hydrocarbons present in fuels. The amount of biodegraded blended diesels was determined by a gravimetric method based on the procedure described by Diaz-Ramirez et al. (2008); an aliquot of $5 \mathrm{~mL}$ of n-hexane was added to the remaining mixture in the $250 \mathrm{~mL}$ Erlenmeyer flask which was transferred to a separation funnel. This process was carried out twice to ensure complete extraction. The separated extracts were treated with $0.4 \mathrm{~g} \mathrm{Na}_{2} \mathrm{SO}_{4}$, which removes the excess water present in $n$-hexane. The treated extract was decanted, leaving the salt behind. The n-hexane was removed from the extract in a rotary evaporator operating at $40 \pm 0.5^{\circ} \mathrm{C}$ under reduced pressure. The weight of the residual blended diesel was measured.

\section{Validity and interpretation of results}

\section{2,6-dichlorophenol indophenol (DCPIP) analysis}

DCPIP was used to validate (as a control) the results of the gravimetric analysis. Higher degradations recorded by gravimetric analysis had to correspond to a change in colour in the tubes (Fig. 1) in the shorter exposure time of the DCPIP test; while the lower degradations recorded by gravimetric analysis had to correspond to relatively longer time for colour change in the test tubes.

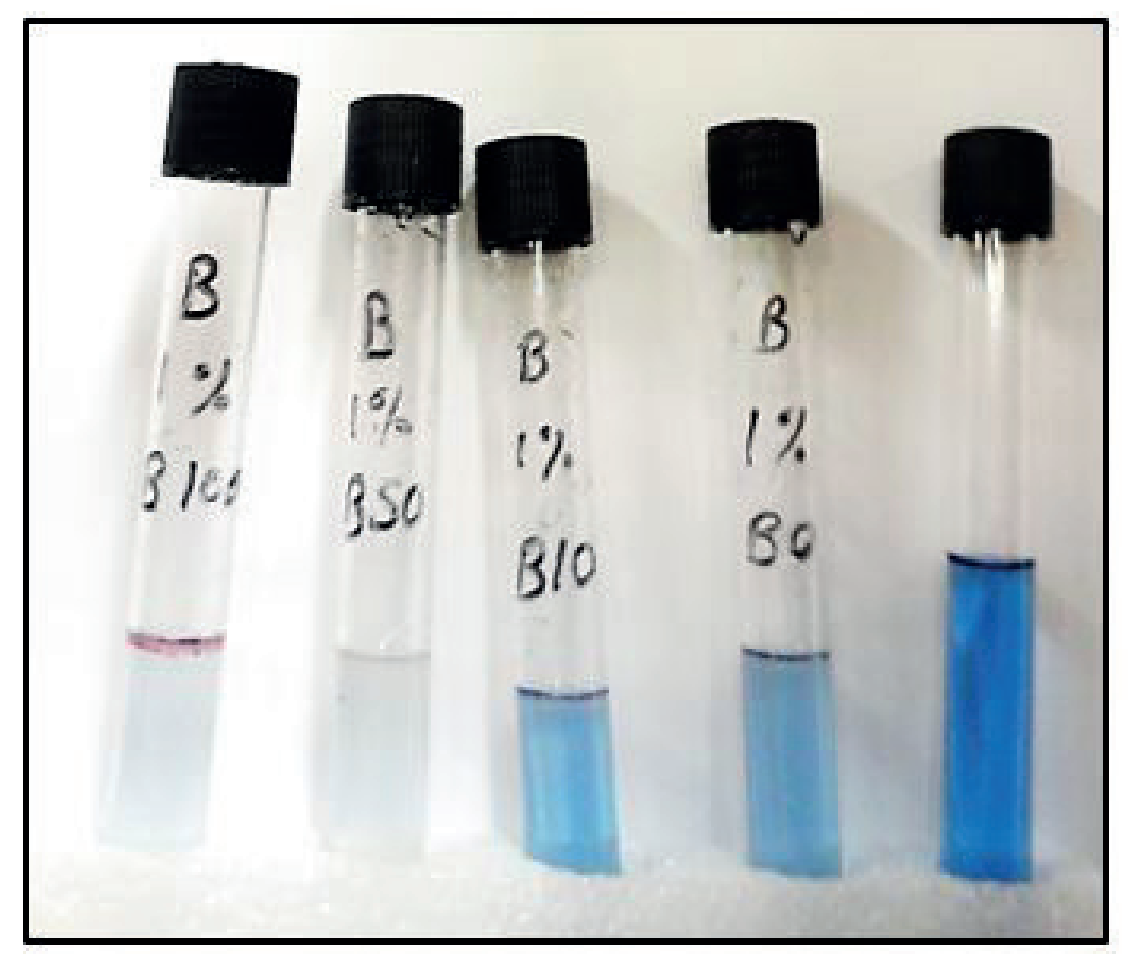

Figure 1. B. subtilis (1\% exposure) DCPIP indicator test for blended diesel (B100, B50, B10, B0 and control from left to right) after 26 hours of incubation at $105 \mathrm{rpm}$ and $30^{\circ} \mathrm{C}$ 
This technique is based on the redox indicator (DCPIP). The inoculum was transferred to a sterile Bushnell-Hass medium $(10 \mathrm{~mL})$ with $1 \%(\mathrm{v} / \mathrm{v})$ of the fuel blends in assay tubes. The DCPIP was added up to a concentration of 20 $\mathrm{mg} / \mathrm{mL}$ and the solution was constantly agitated at $105 \mathrm{rpm}$ and temperature of $30 \pm 0.5^{\circ} \mathrm{C}$; the color change was then monitored over time (Mariano et al., 2008).

\section{Synergism in biodegradation}

A model derived from the concept of Pasqualino et al. (2006) and Mariano et al. (2008) was used in this study to predict the biodegradation value of the blended diesel. The level of error between the model and the experimental values informed about the synergism of the degradation of bio-fossil diesel blends. This was supported by investigating the biodegradation behaviour of the adapted and non-adapted bacteria.

\section{Data analysis}

Experiments were conducted in duplicate with an abiotic control and the percentage experimental errors were used to evaluate the statistical reliability of the data obtained at $95 \%$ confidence interval.

\section{RESULTS AND DISCUSSION}

\section{Comparative adaptive capabilities of $P$. aeruginosa and $B$. subtilis}

Based on their ability to produce surfactant and break down hydrocarbons (Chayabutra and Yu, 2001; Gudina et al., 2013), P. aeruginosa and B. subtilis are often utilized for bioremediation purposes, but their activities are enhanced when they have been previously exposed to the pollutant (Das and Mukherjee, 2007; Kaczorek et al., 2010; Chandankere et al., 2013). The exposure of these species to $1 \%$ and $70 \%(\mathrm{v} / \mathrm{v})$ concentrations of diesel mixture was meant to induce biotransformation that will improve their resistance to diesel as well as trigger the production of surfactants necessary for biodegradation (Tang et al., 2007). Cell growth was monitored during the two week and eight week incubation periods and expressed as CFU counts. A small decline of the growth of both bacteria species was observed after two weeks, but the cells quickly recovered and reached the initial count or more after eight weeks for $P$. aeruginosa and B. Subtilis, respectively. Table 1 shows the CFU counts for both species.

Table 1. The colony forming units (CFU/mL) for the 2 experimental sets over exposure time (weeks)

\begin{tabular}{ccc}
\hline Exposure Time (weeks) & $\boldsymbol{P}$ aeruginosa & B. subtilis \\
\hline & $1^{\text {st }}$ set of experiments $1 \%$ diesel & $8 \times 10^{9}$ \\
\hline 0 & $58 \times 10^{9}$ & $14 \times 10^{7}$ \\
\hline 2 & $16 \times 10^{8}$ & $6 \times 10^{12}$ \\
\hline 8 & $2 \times 10^{9}$ & $22 \times 10^{10}$ \\
\hline 0 & $2 \times 10^{12}$ & $4 \times 10^{9}$ \\
\hline 2 & $13 \times 10^{7}$ & $3 \times 10^{8}$ \\
\hline 8 & $10 \times 10^{5}$ & diesel \\
\hline
\end{tabular}

The initial decline in viable cell growth in both species may be ascribed to the change of substrate and the possible inhibition of cells by the diesel, which contains toxic trace elements such as heavy metals (Yoon-Suk et al., 2009). Hydrocarbons in fossil fuels are reported to alter microbial membrane structures by changing membrane fatty acids and protein composition (Van Hamme et al., 2003). It has been reported (Macnaughton et al., 1999; Yoon-Suk et al., 2009) that contamination of diesel results in less diverse microbial communities in the ecosystem due to the susceptibility of microorganisms to stressful conditions, but as observed in this study, microbial communities recover following adaptation (Roling et al., 2002).

The effect of diesel concentration was not conclusive as the inhibition of $P$. aeruginosa increased with the diesel concentration while the opposite trend was observed with $B$. subtilis. It was observed that $P$. aeruginosa was more susceptible to the presence of diesel than B. Subtilis, which is likely due to the fact that the latter have the potential to form endospores when exposed to stressful conditions (Nicholson et al., 2000).

\section{Biodegradation potential of induced $B$. subtilis and $\boldsymbol{P}$. aeruginosa}

The induced cells were used to degrade various grades of blended diesel. Figs. 2 and 3 show that the degradation rate increased with the concentration of biodiesel in the blend.

To determine the influence of the concentration of diesel and exposure time during induction, the cells induced in $1 \%$ and $70 \%$ diesel mixtures for two weeks and eight weeks were used for the biodegradation of blended diesel. Fig. 2 shows that the cells of B. subtilis exposed to $1 \%$ and $70 \%$ diesel mixtures for eight weeks achieved the highest biodegradation rate of $\mathrm{B} 0 ; \mathrm{B} 10$ and $\mathrm{B} 50$, while the 
cells exposed for only two weeks were most effective in the degradation of pure biodiesel. This could be ascribed to the fact that longer exposure and higher concentration of diesel may stimulate biotransformation, enabling tolerance to diesel as well as a change of nutrient priority, as the microorganism has now synthesized enzymes for the use of new substrates or combination of substrates.

A different trend was observed when $P$. aeruginosa cells induced under similar conditions ( $1 \%$ and $70 \%)$ were used for biodegradation of diesel blends. Fig. 3 shows that, although the cells induced in $70 \%$ diesel mixture were the most effective during the degradation of B0, the cells induced in $1 \%$ diesel mixture for two weeks performed better than the other cells when degrading B10; B50 and B100. Tang et al. (2007) also observed that $P$. aeruginosa exposed to crude oil was not able to emulsify or biodegrade crude oil; there was a need in that case to expose the cells to glycerol for stimulation of the production of the surfactant rhamnolipids useful for biodegradation.

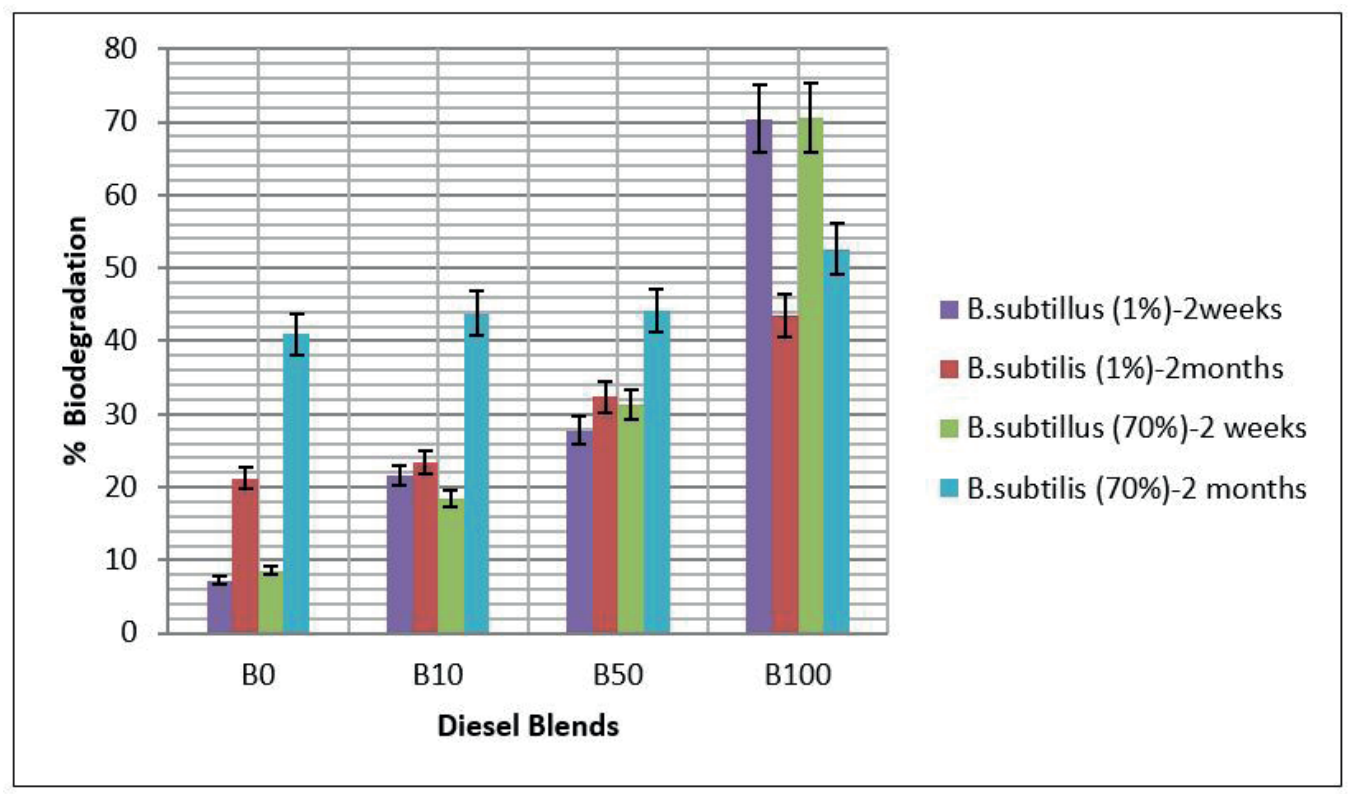

Figure 2. Biodegradation of diesel blends by induced B. subtilis

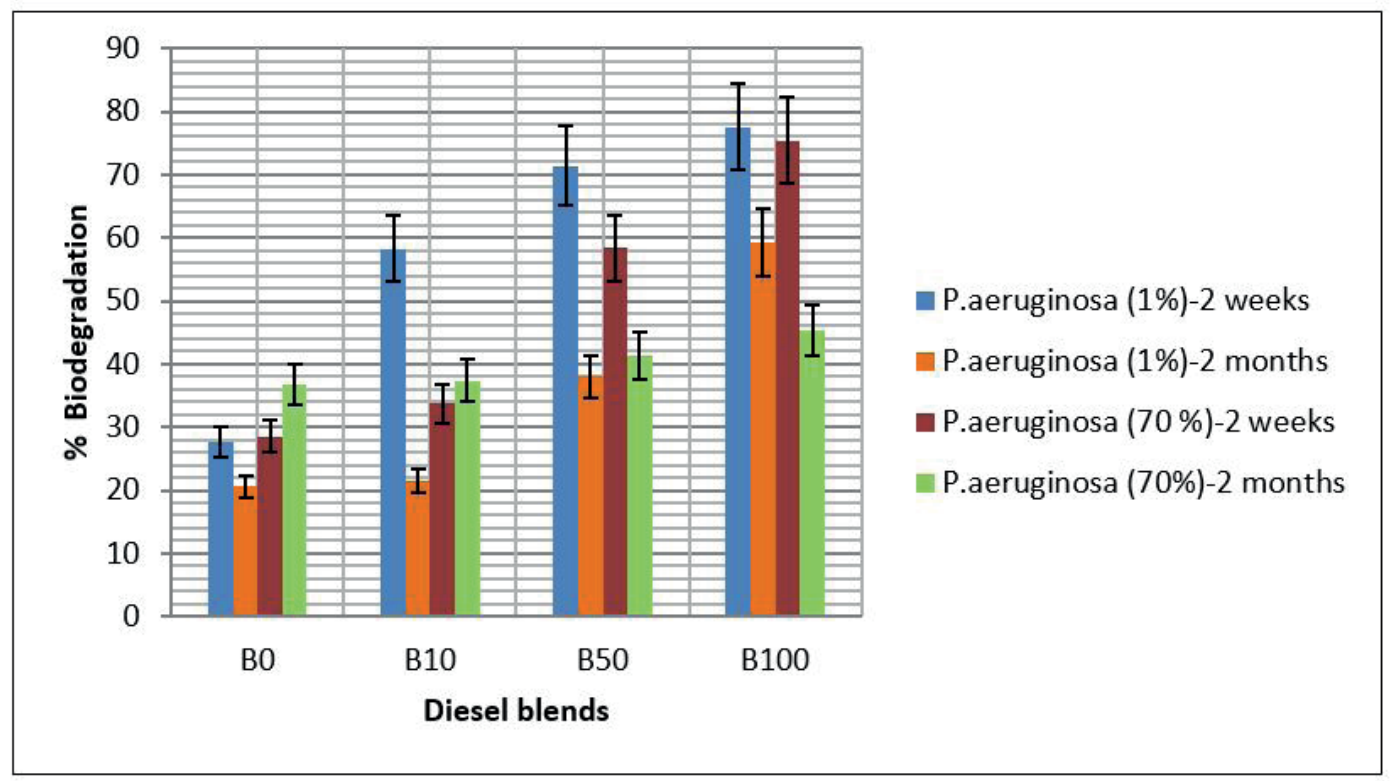

Figure 3. Biodegradation of diesel blends by induced $P$. aeruginosa 
The comparison of the trends in Figs. 2 and 3 could elucidate the effect of induction time on the biodegradation potential. It can therefore be seen that, from two weeks to eight weeks induction time, there was an increase of the capacity of $B$. subtilis to degrade fuel containing fossil diesel. An increase in capacity of $14 \%, 10 \%$ and $5 \%$ was recorded as the cells induced in $1 \%$ diesel mixtures degraded B0; B10 and B50 blends, respectively, while the increases of the performance of the cells induced in $70 \%$ diesel mixtures were 33\% (B0); 26\% (B10) and 13\% (B50). It is plausible that, with time, B. subtilis species improve the mechanism to tolerate diesel oil, and metabolise proteins required for the breakdown of complex molecules of the diesel. The adaptation capability of $B$. subtilis is clearly illustrated in Table 1, where the decrease of cell growth after two weeks is followed by a recovery after eight weeks of exposure to diesel.

This trend was, however, not observed with $P$. aeruginosa; Fig. 3 indicates that the longer induction time resulted in the decrease of the biodegradation capability of P. aeruginosa, although the cells exposed for eight weeks in $70 \%$ diesel mixture did perform better for the degradation of $\mathrm{B} 0$ and $\mathrm{B} 10$ than their counterparts that were exposed for two weeks. According to Tang et al. (2007), stressful conditions in the crude oil may reduce the ability of $P$. aeruginosa ZJU to produce surfactants required for crude oil degradation.

\section{Concept of bacteria adaptation and degradation of diesel blend}

It is difficult to evaluate the performance of non-adapted and adapted species in blended diesel, given the challenge to start each individual experiment with the same amount of cells. Therefore, a method of calculation is needed to evaluate the adaption, irrespective of the starting amount of cells.

It was suggested by Zang et al. (1998) that the presence of biodiesel (B100) in diesel blend (B0) could assist in the biodegradation of fossil diesel (B0) even faster than the fossil diesel would degrade as a pure species. Since most organisms struggle to biodegrade fossil diesel (B0), nutrient supplementation is often needed. In blended diesel the biodiesel (B100) is assumed to accelerate the biodegradation of fossil diesel. Faster degradation of the blend was observed (Fig. 2 and 3) at higher concentration of biodiesel. A model was proposed by Pasqualino et al. (2006) and Mariano et al. (2008) to evaluate the effect of the addition of biodiesel on the degradation of fossil diesel in the diesel blend. The model was based on the production of $\mathrm{CO}_{2}$, a by-product of microbial biodegradation.

$$
L C=D .\left(\mathrm{CO}_{2}\right)_{B 0}+B \cdot\left(\mathrm{CO}_{2}\right)_{B 100}
$$

where $\mathrm{LC}$ is the total level of $\mathrm{CO}_{2}$ derived from microbial biodegradation, $\mathrm{D}$ is the fraction of fossil diesel present, $\mathrm{B}$ the fraction of biodiesel present, $\left(\mathrm{CO}_{2}\right)_{B 0}$ the amount of $\mathrm{CO}_{2}$ produced by pure fossil diesel as by-product of biodegradation and $\left(\mathrm{CO}_{2}\right)_{B 100}$ is the amount of $\mathrm{CO}_{2}$ produced by pure biodiesel as by-product of biodegradation. A similar model could be derived for the interpretation of the gravimetric analysis results in this study; assuming that:

$$
\mathrm{CO}_{2} \text { produced }=\% \text { Biodegradation }
$$

The derived equation that was then used in this study is shown below;

$$
\begin{gathered}
\quad(\% B D)_{B l e n d} \text { Predict }= \\
=D \cdot(\% \text { Biodegradation })_{B 0}+ \\
+B .(\% \text { Biodegradation })_{B 100}
\end{gathered}
$$

where $\mathrm{D}$ is the fraction of fossil diesel in the blend, $\mathrm{B}$ is the fraction of biodiesel in the blend, $(\% \text { Biodegradation })_{B 0}$ is the $\%$ biodegradation obtained from the experiments for pure fossil diesel, (\%Biodegradation $)_{B 100}$ is the $\%$ biodegradation obtained from the experiments for pure biodiesel and $(\% B D)_{B l e n d}$ Predict is the predicted biodegradation value for the specific blended diesel.

The meaning of equation (3) could be explained by the following scenarios;

- If the predicted value for the biodegradation $\left((\% B D)_{\text {Blend }}\right.$ Predict $)$ and the actual experimental biodegradation data for a specific blend (e.g., B10) are more or less the same, i.e., $(\% B D)_{\text {Blend }}$ Predict $)$ $=(\% B D)_{\text {Blend }}$ Experimental $)$, then the addition of biodiesel (B100) did not contribute to enhance the biodegradation of fossil diesel (B0) in the blend.

- If the predicted value for the biodegradation () and the actual experimental biodegradation data for a specific blend (e.g., B10) differ greatly from one another, i.e., $(\% B D)_{\text {Blend }}$ Predict \# $(\% B D)$ ${ }_{B l e n d}$ Experimental, then the addition of biodiesel (B100) contributed greatly to enhance the biodegradation of fossil diesel (B0) in the blend.

Therefore, the error $\left(E_{d}\right)$ between the predicted value of biodegradation and the actual experimental biodegradation results for a specific blend would give an indication as to what extent the biodiesel (B100) in the blend helped enhance the biodegradation of fossil diesel (B0).

$E_{d}=\mid$ Experimental value - Model predicted value 
Therefore, to summarise the concept, the larger the $E_{d}$ value becomes, the more biodiesel (B100) assists in the biodegradation of fossil diesel (B0). The smaller $E_{d}$ value becomes, the less biodiesel (B100) assists in the biodegradation of fossil diesel (B0).

\section{Evaluation of the adaptation of bacterial species in fossil diesel}

The level of adaptation could then be calculated using a similar approach as described above. The following assumptions are made;

- If the species adapted to the fossil diesel (B0) (adaptation induced at various concentrations of fossil diesel and exposure times), then the species would not rely most on nutrient supplementation such as biodiesel (B100) when inoculated in blended diesel. This is explained by the fact that an adapted cell can consume fossil diesel (B0).

- If the species did not adapt after exposure to fossil diesel, then the species would benefit from the addition of a secondary nutrient source such as biodiesel (B100) when the species is inoculated in blended diesel. This is explained by the fact that non-adapted cells struggle to consume the fossil diesel (B0) in the blend and therefore a secondary easily consumable nutrient (B100) is needed for microbial survival in blended diesel.

Relating these assumptions to the initial statement, the following could be said for adapted and non-adapted cells as a function of the value. It could be assumed that the adapted cells would have small values because theoretically the adapted cells would prefer fossil diesel or rather the addition of biodiesel (B100) would not alter the biodegradation of fossil diesel (B0) since these cells could already consume fossil diesel (B0). Then it is valid to assume that the model and experimental values would be relatively the same. Consequently, a small error will be expected because there is a small difference between the model prediction values and the experimental values.

It could also be assumed that the non-adapted cells will have larger values because the bacterial species did not adapt and consequently a secondary nutrient source (B100) is necessary to assist in the biodegradation of fossil diesel (B0). Therefore, the model prediction value and experimental value will differ significantly for low blends $(<\mathrm{B} 10)$, leading to large values of .

The adapted cells do not depend on a secondary nutrient source (B100) in a low blended diesel (B10); therefore, these cells should have small values. Non-adapted cells are highly dependent on a secondary nutrient source because of the inability to consume the fossil diesel (B0) in low diesel blends (e.g., B10).

\section{Influence of parameters on cell adaptation and biodegradation potential}

\section{Diesel concentration and cell adaptation}

The theory and formulas stated above are used to evaluate the adaptability of bacterial species using the experimental data from the gravimetric analysis. To evaluate the effect of the fossil diesel concentration on the adaption capabilities, the values were calculated for the B10 blend (considered as the blend with higher fossil diesel concentration in this study). One would expect the bacterial species to adapt more rapidly when induced in $70 \%$ diesel mixture as compared to the $1 \%$ diesel mixture. So according to the theory described above, the cells exposed to $70 \%$ diesel mixture are likely to exhibit smaller values when compared with the cells exposed to $1 \%$ diesel mixture. The experimental and calculated data are expressed in Table 2.

It is very important to note that the $\%$ biodegradation for adapted cells is lower due to the fact that the experiment started with fewer cells. Therefore, one must look at the values to determine the exact effect.

The calculations above showed that, as expected, the cells that were exposed to $70 \%$ diesel mixture exhibited lower values and the cells that were less likely to adapt after exposure to $1 \%$ diesel mixture exhibited higher values. This therefore corroborates the principles stipulated above.

Theoretically $P$. aeruginosa exposed to $70 \%$ diesel mixture will develop a quick biotransformation and therefore higher biodegradation capability. Fig. 4 shows that the trend of biodegradation by $P$. aeruginosa species induced in higher concentrations (70\%) of fossil diesel (B0) is almost similar to the predicted trend; this was also observed with $B$. subtilis species induced under the same conditions. Based on the above data, higher performance of $B$. subtilis species will be expected after induction in

Table 2. $\mathrm{E}_{\mathrm{d}}$ values derived from the effect of diesel concentration on the adaptation of cells and degradation of B10 blends

\begin{tabular}{|c|c|c|c|c|}
\hline \multirow{2}{*}{ Induced cell results for $\underline{\mathrm{B} 10}$} & \multicolumn{2}{|c|}{$\%$ Biodegradation } & \multirow{2}{*}{$E_{d}$ value $(\%)$} & \multirow{2}{*}{$\begin{array}{l}\text { Starting amount of cells } \\
(\mathrm{CFU} / \mathrm{mL})\end{array}$} \\
\hline & Experimental Values & Model prediction & & \\
\hline P. aeruginosa $(1 \%)$ & $58.25 \pm 5.18$ & $32.70 \pm 2.94$ & $25.5 \pm 0.68$ & $123 \times 10^{7}$ \\
\hline P. aeruginosa $(70 \%)$ & $33.679 \pm 2.99$ & $33.20 \pm 2.92$ & $0.47 \pm 0.08$ & $130 \times 10^{6}$ \\
\hline B. subtilis $(1 \%)$ & $21.61 \pm 1.45$ & $13.58 \pm 0.91$ & $8.03 \pm 0.43$ & $3 \times 10^{10}$ \\
\hline B. subtilis $(70 \%)$ & $18.4426 \pm 1.26$ & $14.75 \pm 1.01$ & $3.70 \pm 0.82$ & $4 \times 10^{9}$ \\
\hline
\end{tabular}




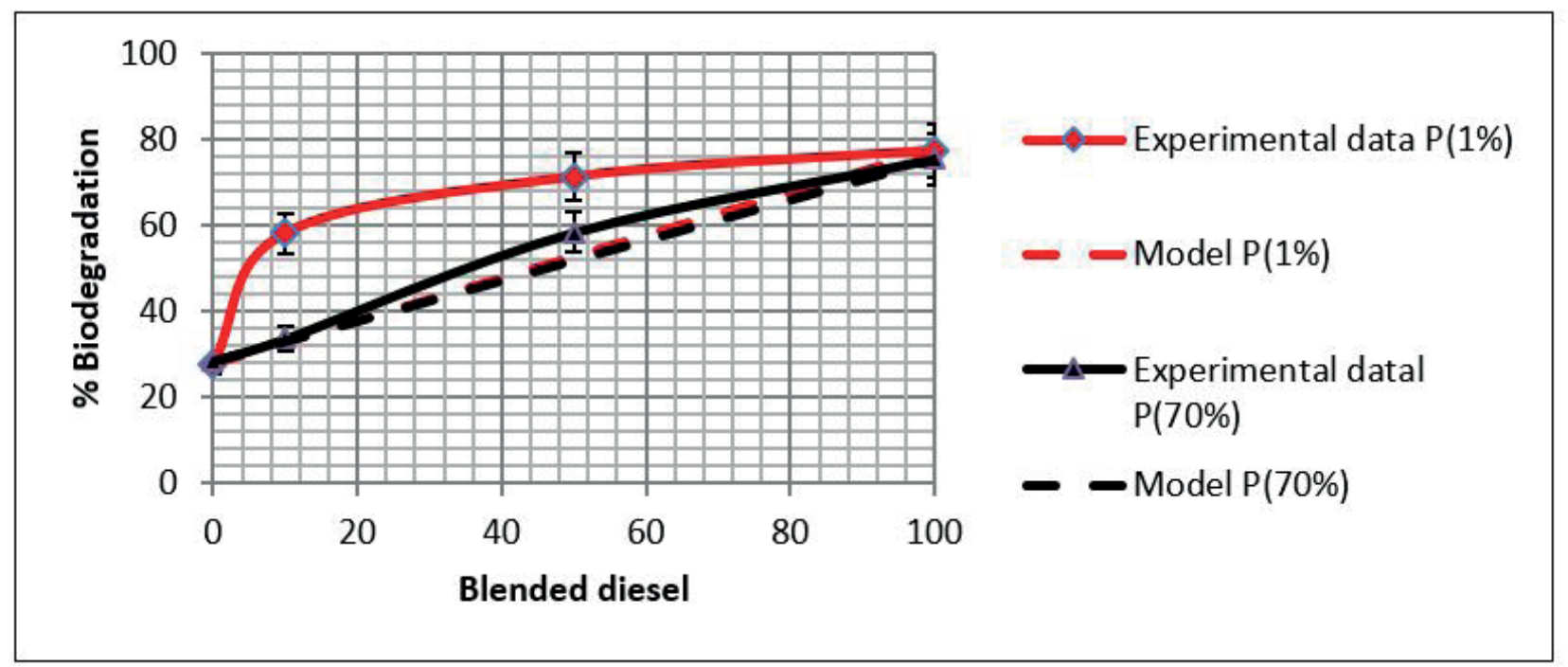

Figure 4. Comparison between experimental data and predicted values for $P$. aeruginosa exposed to $70 \%$ and $1 \%$ diesel mixture.

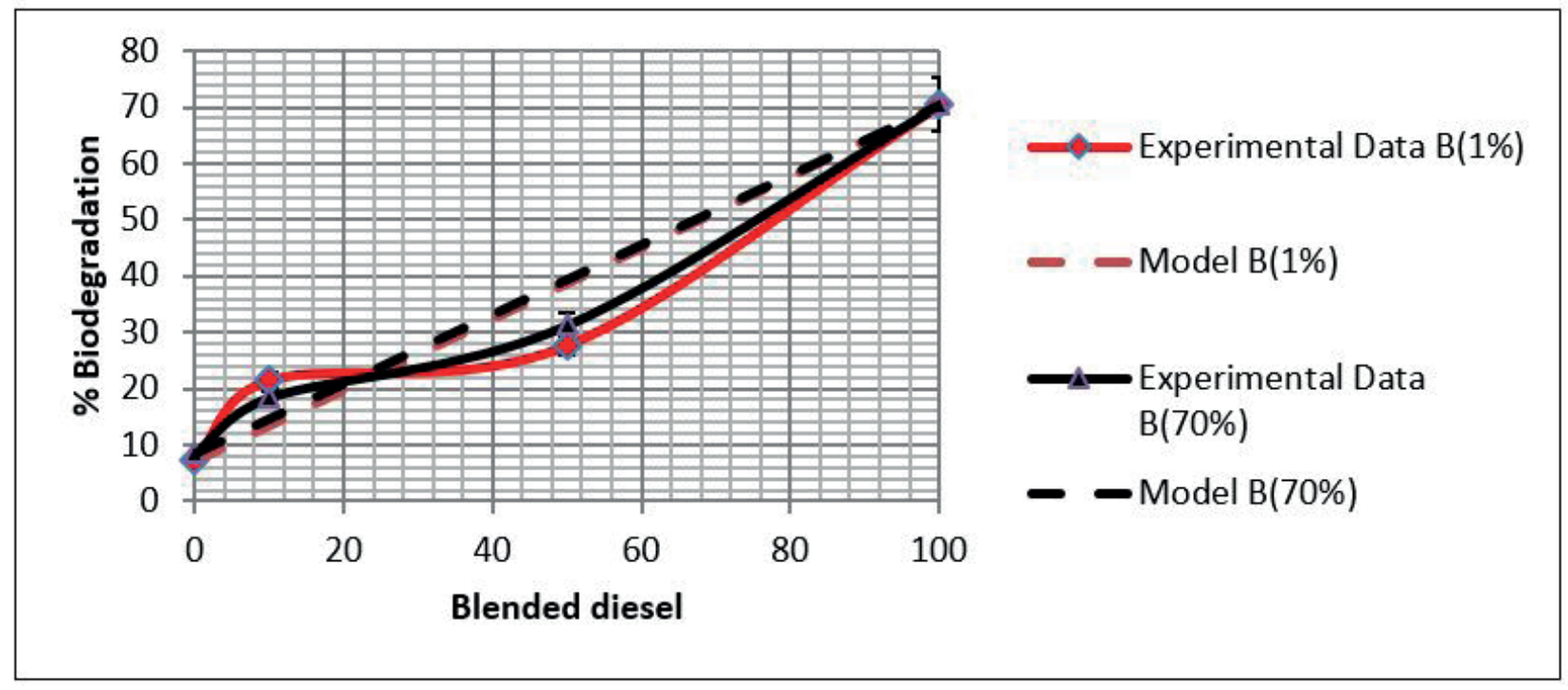

Figure 5. Comparison between experimental data and model predicted values for B. subtilis exposed at $70 \%$ and $1 \%$ diesel mixture.

$70 \%$ diesel mixture, which is confirmed in Fig. 5 as the biodegradation trend exhibited by cells previously induced in $70 \%$ diesel mixtures is much closer the predicted trend compared to the cells induced in $1 \%$ diesel mixture.

Overall it could be noted that the more likely a species is to adapt, the less the experimental data would deviate from the model line. A similar observation was found for the cells induced for eight weeks.

In Fig. 3 above it appears that the less adapted cells (1\%) biodegraded the blends to a much higher extent compared to the $70 \%$ induced cells. This could be attributed to the relatively higher number of starting cells.
Consequently, the values give a good indication of the extent of cell adaptation. The values for both species exposed to $1 \%$ and $70 \%$ diesel mixtures are shown in Figs. $6 \& 7$. These figures show that the cells induced in $1 \%$ diesel mixtures had larger values when compared to the cells induced in $70 \%$ diesel mixtures. The values reported in Table 2 clearly indicate that the cells easily adapt at higher concentration of diesel, improving their biodegradation potential.

In order to normalize the data a method consisting of calculating the grams of oil used per starting CFU/mL was considered. 


$$
\frac{g}{\frac{C F U}{m l}}=\frac{(\text { Oil consumed })}{\frac{C F U}{m l}}
$$

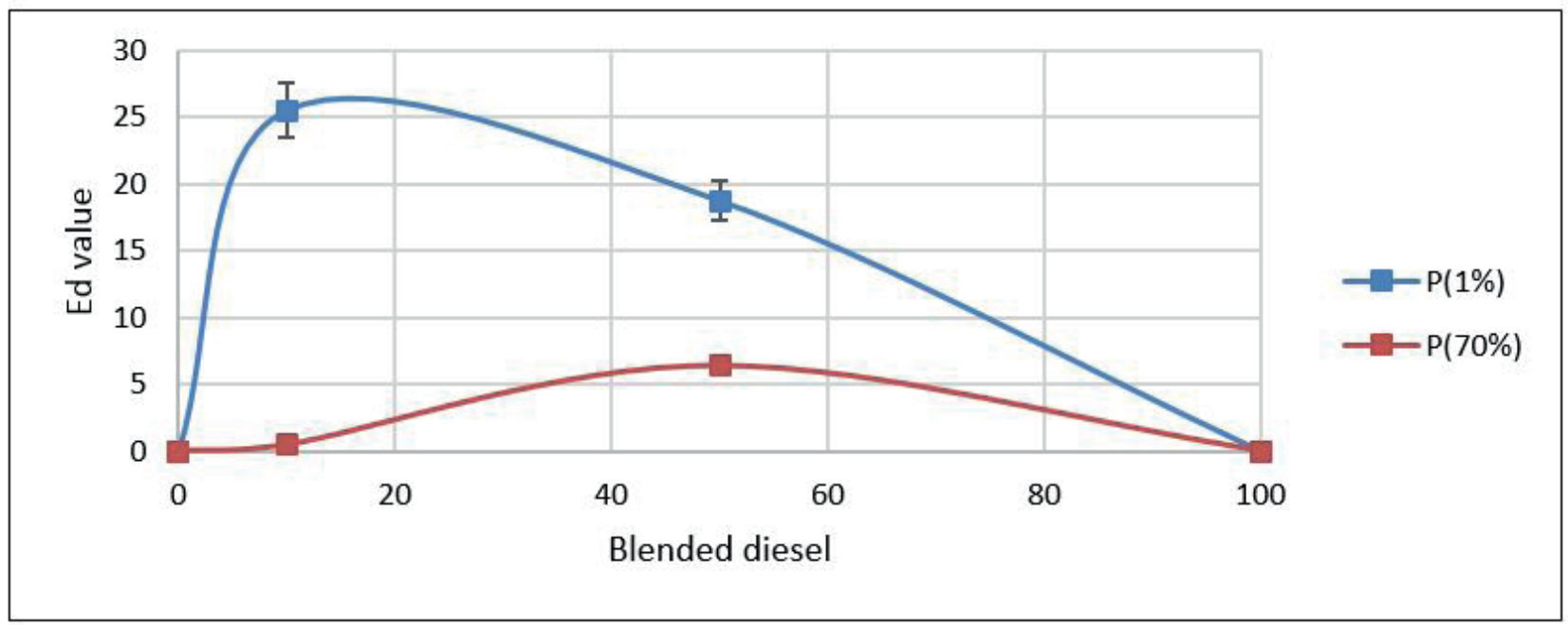

Figure 6. The value for the biodegradation of different blends by $P$. aeruginosa induced in $1 \%$ and $70 \%$ diesel mixture

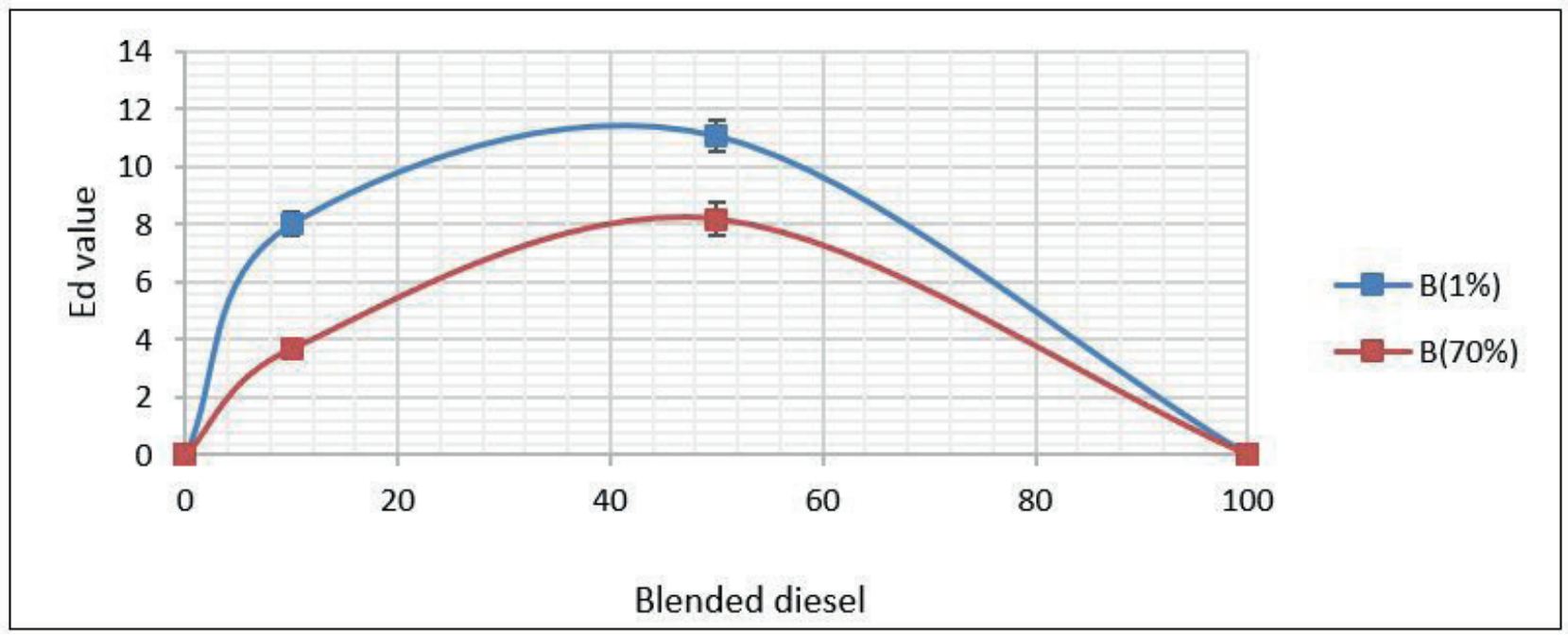

Figure 7. The value of the biodegradation of different blends by $B$. subtilis induced in $1 \%$ and $70 \%$ diesel mixture

Table 3. Normalization of data in terms of grams of oil used per CFU/mL $\left(10^{10}\right)$

\begin{tabular}{lcccc}
\hline \multirow{2}{*}{ Blended diesel } & \multicolumn{5}{c}{ Grams oil used per starting CFU/mL $\left(10^{10}\right)$} \\
\cline { 2 - 5 } & P. aeruginosa $(1 \%)$ & P. aeruginosa $(70 \%)$ & B. subtilis $(1 \%)$ & B. subtilis $(70 \%)$ \\
\hline B0 & 2.44 & 25.77 & 0.0236 & 0.225 \\
\hline B10 & 4.82 & 25.45 & 0.0733 & 0.470 \\
\hline B50 & 5.74 & 44.45 & 0.0910 & 0.807 \\
\hline B100 & 6.21 & 58.38 & 0.2320 & 1.78 \\
\hline
\end{tabular}


The biodegradation capabilities of $P$. aeruginosa and $B$. subtilis induced in $70 \%$ diesel mixture are reported as grams of oil used per starting CFU/mL in Figs. 8 and 9. It could be observed that taking into account the starting number of cells gives a clear estimate of the ability of the species to degrade the blended diesel; therefore, the induction of cells at higher concentration (70\%) of diesel clearly stimulated biotransformation in the bacteria, enabling effective use of the blended diesel. This confirms the findings by Striebich et al. (2014) that the degradation profile of an organism is determined by its intrinsic metabolic function. On the other hand, it could be observed that the biodegradation potential of $P$. aeruginosa is higher compared to B. Subtilis; this allows to differentiate the ability for the species to tolerate the fossil diesel with regard to inhibition and its ability to actually use fossil diesel as nutrient.

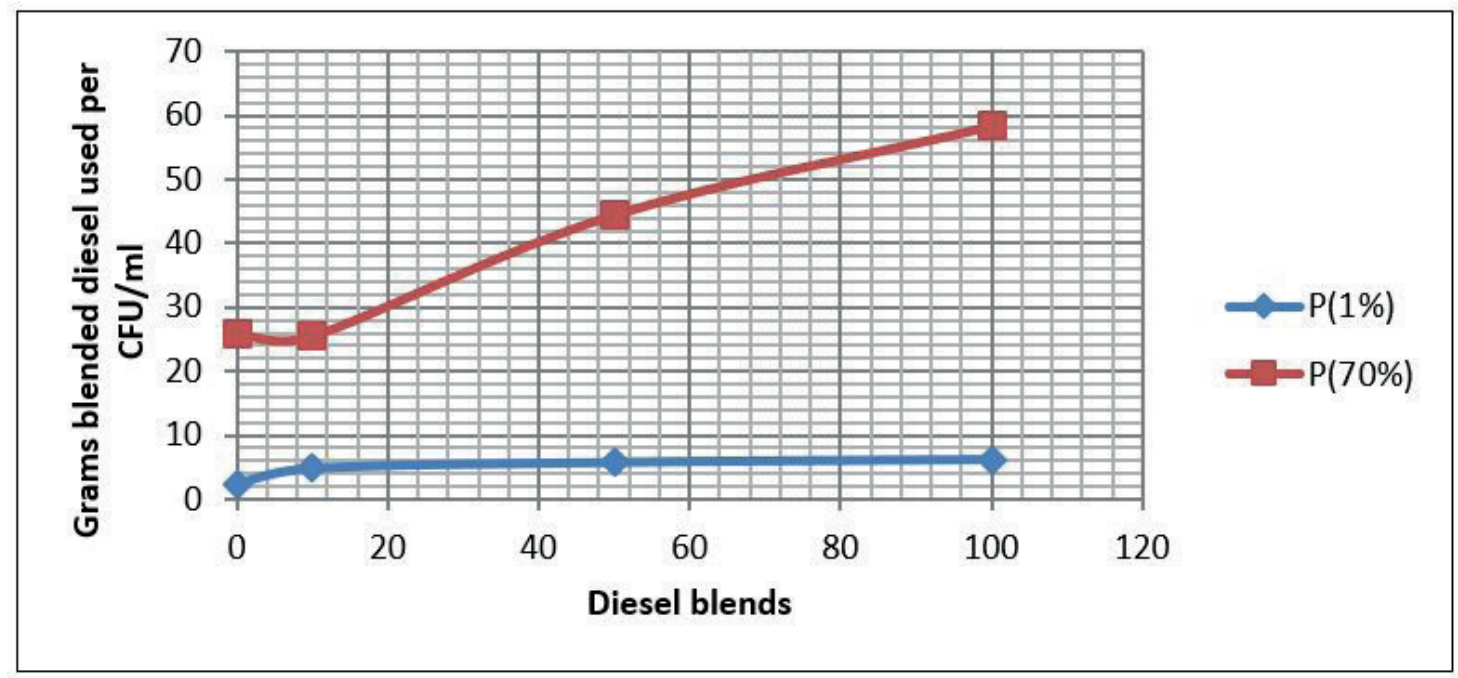

Figure 8. Grams blended diesel used per starting CFU/mL $\left(10^{10}\right)$ for $P$. aeruginosa induced in $1 \%$ and $70 \%$ diesel mixture.

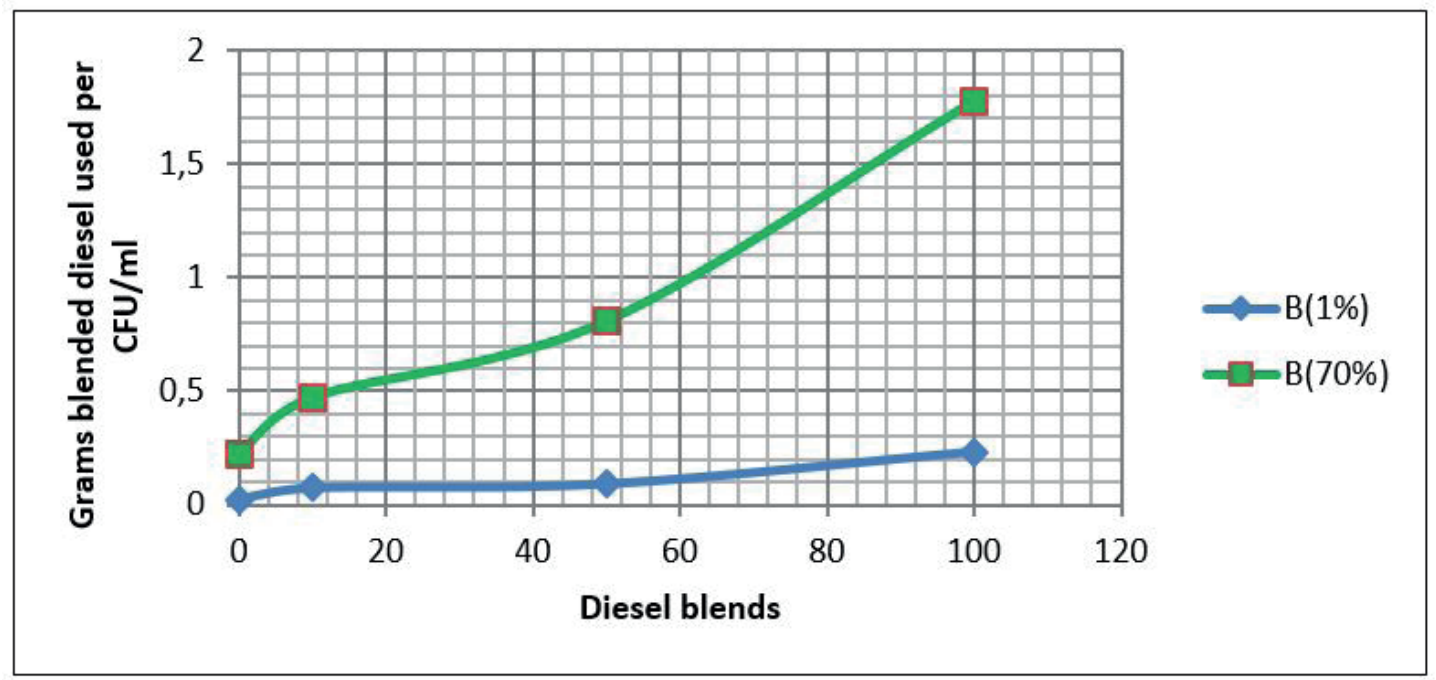

Figure 9. Grams blended diesel used per starting CFU/mL $\left(10^{10}\right)$ for $\mathrm{B}$. subtilis induced in $1 \%$ and $70 \%$ diesel mixture

\section{CONCLUSION}

It was possible to ascertain in this study the conditions under which the synergy of fuel could promote biodegradation. The use of the $E_{d}$ values showed that the synergy was more beneficial for less adapted cells while the cells that have effectively adapted tend to preferably utilise the fossil diesel in the blend. The induction of cells was found to be effective when they were exposed to a higher concentration of fossil diesel for a longer period of time. The findings in this study can be used to enhance the capacity of microorganisms during bioremediation of polluted areas. 


\section{ACKNOWLEDGEMENT}

The authors are grateful to the contribution of Mr G. van Rensburg from the North-West University.

\section{REFERENCES}

Adebusoye, S.A., Ilori, M.O., Amund, O.O., Teniola, O.D. and Olatope, S.O., Microbial degradation of petroleum hydrocarbons in a polluted tropical stream. World Journal of Microbiology and Biotechnology, 23, No. 8, 1149 (2007).

Atlas, R.M., Microbial degradation of petroleum hydrocarbons: an environmental perspective. Microbiology Review, 45, 180 (1981).

Banat, I.M., Makkar, R.S. and Mameotra, S.S., Potential of commercial applications of microbial surfactants. Applied Microbiol. Biotechnol., 53, 495 (2000).

Bucker, F., Santestevan, N.A., Roesch, L.F., Jacques, R.J.S., Peralba, M. do C.R., Camargo, F.A. de O. and Bento, F.M., Impact of biodiesel on biodeterioration of stored Brazilian diesel oil. International Biodeterioration and Biodegradation, 65, 172 (2011).

Bundy, J.G., Paton, G.I. and Campell, C.D., Microbial communities in different soil types do not converge after diesel contamination. Journal of Applied Microbiology, 92, 276 (2002).

Chandankere, R., Yao, J., Choi, M.M.F., Masakorala, K. and Chan, Y., An efficient biosurfactant-producing and crude-oil emulsifying bacterium Bacillus methylotrophicus USTBa isolated from petroleum reservoir. Biochemical Engineering Journal, 74, 46 (2013).

Chayabutra, C. and Ju, L.K., Polyhydroxyalkanoic acids and rhamnolipids are synthesized sequentially in hexadecane fermentation by Pseudomonas aeruginosa ATCC 10145. Biotechnol Programme, 17, No. 3, 419 (2001).

Das, K. and Mukherjee, A.K., Crude petroleum-oil biodegradation efficiency of Bacillus subtilis and Pseudomonas aeruginosa strains isolated from a petroleum-oil contaminated soil from North-East India. Bioresource Technology, 98, 1339 (2007).

Diaz-Ramirez, I.J., Escalante-Espinosa, E., Favela-Torres, E., Gutierrez-Rojas, M. and Ramirez-Saad, H., Design of bacterial defined mixed cultures for biodegradation of specific crude oil fractions, using population dynamics analysis by DGGE. International Biodegradation and Biodeterioration, 62, 21 (2008).

Dlamini, N.P., Mamba, B.B. and Mulaba-Bafubiandi, A.F., The effect of silica concentration on the biosorption of $\mathrm{Cu}^{2+}$ and $\mathrm{Co}^{2+}$ from aqueous solutions mediated by strains of Bacillus. Water SA, 36, No. 4, 445 (2010).
Fei, Ng. Y., Ge, L., Chan, W.K., Tan, S.N., Yong, J.W.H. and Tan, T.T.Y., An environmentally friendly approach to treat oil spill: Investigating the biodegradation of petrodiesel in the presence of different biodiesels. Fuel, 139, 523 (2015).

Gudina, E.J., Pereira, J.F.B., Costa, R., Coutinho, A.P., Teixeira, J.A. and Rodrigues, L.R., Biosurfactantproducing and oil-degrading Bacillus subtilis strains enhance oil recovery in laboratory snad-pack columns. Journal of Hazardous Materials, 261, 106 (2013).

Kaczorek, E., Urbanowicz, M. and Olszanowski, A., The influence of surfactants on cell surface properties of Aeromonas hydrophila during diesel oil biodegradation. Colloids and Surfaces B: Biointerfaces, 81, 363 (2010).

Kleinsteuber, S., Riis, V., Fetzer, I., Harms, H. and Muller, S., Population dynamics within a microbial consortium during growth on diesel fuel in saline environments. Applied Environmental Microbiology, 72, No. 5, 3531 (2006).

Krumholz, L.R., Microbial ecosystems in the earth's subsurface. American Society for Microbiology News, 64, 197 (1998).

Leahy, J.G. and Cowell, R.R., Microbial degradation of hydrocarbons in the environment. Microbiology Review, 54, 305 (1990).

Macnaughton, S.J., Stephen, J.R., Venosa, A.D., Davis, G.A., Chang, Y-J. and White, D.C., Microbial population changes during bioremediation of an experimental oil spill. Applied and Environmental Microbiology, 3566 (1999).

Maila, M.P., Randima, P., Surridge, K., Drønen, K. and Cloete, T.E., Evaluation of microbial diversity of different soil layers at a contaminated diesel site. International Biodeterioration \& Biodegradation, 55, 39 (2005).

Margesin, R. and Schinner, F., Bioremediation (natural attenuation and biostimulation) of diesel-oilcontaminated soil in an alpine glacier skiing area. Applied and Environmental Microbiology, 67, No. 7, 3127 (2001).

Mariano, A.P., Tomasella, R.C., de Oliveira, M.L., Contiero, J. and de Angelis, D.F., Biodegradability of diesel and biodiesel blends. African Journal of Biotechnology, 7, 1323 (2008).

Meyer, D.D., Beker, S.A., Bucker, F., Peralba, M. do C.R., Frazzon, A.P.G., Osti, J.F., Andreazza, R., Camargo, F.A. de O. and Bento, F.M., Bioremediation strategies for diesel and biodiesel in oxisol from southern Brazil. International Biodeterioration and Biodegradation, 95, 356 (2014).

Michaud, L., Giudice, A.L., Saitta, M., De Domenico, M. and Bruni, V., The biodegradation efficiency on diesel 
oil by two psychrotrophic Antarctic marine bacteria during a two-month-long experiment. Marine Pollution Bulletin, 49, 405 (2004).

Mittal, H., Fosso-Kankeu, E., Mishra, S.B. and Mishra, A.K., Biosorption potential of Gum ghatti-gpoly(acrylic acid) and susceptibility to biodegradation by $B$. subtilis. International Journal of Biological Macromolecules, 62, 370 (2013).

Nicholson, W.L., Munakata, N., Horneck, G. and Melosh, H.J., Resistance of Bacillus endospores to extreme terrestrial and extraterrestrial environments. Microbiology Molecular Biotechnoogyl Review, 64, 548 (2000).

Norman, R.S., Moeller, P., McDonald, T.J. and Morris, P.J., Effect of pyocyanin on a crude-oil-degrading microbial community. Applied and Environmental Microbiology, 70, No. 7, 4004 (2004).

Owsianiak, M., Chrzanowski, L., Szulc, A., Staniewski, J., Olszanowski, A., Olejnik-Schmidt, A.K. and Heipieper H.J., Biodegradation of diesel/biodiesel blends by a consortium of hydrocarbon degraders: effect of the type of blend and the addition of biosurfactants. Bioresource Technology, 100, 1497 (2009).

Pasqualino, J.C., Montane, D. and Salvado, J., Synergic effects of biodiesel in the biodegradability of fossilderived fuels. Biomass Bioenergy, 30, 874 (2006).

Ribeiro, H., Mucha, A., Almeida, M.R. and Bordalo, A.A., Bacterial community response to petroleum contamination and nutrient addition in sediments from a temperate salt marsh. Science of the Total Environment, 458-460, 568 (2013).

Roling, W.F.M., Milner, M.G., Jones, D.M., Lee, K., Daniel, F., Swannell, R.J.P. and Head, I.M., Robust hydrocarbon degradation and dynamics of bacterial communities during nutrient-enhanced ois spill bioremediation. Applied Environmental Microbiology, 5537 (2002).

Sorensen, G., Pedersen, D.V., Norgaard, A.K., Sorensen, K.B. and Nygaard, S.D., Microbial growth studies in biodiesel blends. Bioresource Technology, 102, 5259 (2011).

Tang, X., Zhu, E.Y. and Meng, Q., Enhanced crude oil biodegradability of Pseudomonas aeruginosa ZJU after preservation in crude oil-containing medium. World Journal Microbiology and Biotechnology, 23, 7 (2007).

Vacca, D.J., Bleam, W.F. and Hickey, W.J., Isolation of soil bacteria adapted to degrade humic acid-sorbed phenanthrene. Applied Environmental Microbiology, 71, No. 7, 3797 (2005).

Van, Hamme, J.D., Singh, A. and Ward, O.P., Recent advances in petroleum microbiology. Microbiology and Molecular Biology Review, 67, 503 (2003).

Yoon-Suk, K., Park, Y.J., Jung, J. and Park, W., Inhibitory effect of aged petroleum hydrocarbons on the survival of inoculated microorganism in a crude-oil-contaminated site. Journal of Microbiological Biotechnology, 19, No. 12, 1672 (2009).

Zhang, X., Peterson, C., Reece, D., Haws, R. and Moller, G., Biodegradability of biodiesel in the aquatic environment. Trans ASAE, 41, 1423 (1998).

Zhen-Yu, W., Dong-Mei, G., Feng-Min, L., Jian, Z., YuanZheng, X., Simkins, S. and Bao-Shan, X., Petroleum hydrocarbon degradation potential of soil bacteria native to the Yellow River Delta. Pedosphere, 18, No. 6, 707 (2008). 